\title{
Benign Kidney Neoplasm
}

National Cancer Institute

\section{Source}

National Cancer Institute. Benign Kidney Neoplasm. NCI Thesaurus. Code C4778.

A non-metastasizing neoplasm that arises from the kidney. Representative examples

include cystic nephroma, metanephric adenoma, oncocytoma, and urothelial papilloma of the renal pelvis. 